\title{
Uptake, transformation, and impact of selenium in freshwater phytoplankton and bacterioplankton communities
}

\author{
Gerhardt F. Riedel*, James G. Sanders, Cynthia C. Gilmour \\ The Academy of Natural Sciences, Benedict Estuarine Research Center, St. Leonard, Maryland 20685, USA
}

\begin{abstract}
The uptake, transformation and effects of selenium on natural plankton communities from a freshwater reservoir with a history of selenium contamination were examined. The majority of uptake occurred by particles $>0.8 \mu \mathrm{m}$, reflecting the dominance of biomass by phytoplankton. Selenium uptake was proportional to plankton biomass and selenium concentration. Short-term uptake (0 to $24 \mathrm{~h})$ of selenite was approximately 4 to 5 times faster than that of selenate. In long-term cultures, the relative rates of selenate uptake by size classes varied with the distribution of biomass among size classes. The only transformation of selenium observed was an increase in selenite in long-term cultures enriched with selenate. Selenate concentrations of $127 \mathrm{nM}$ caused a significant reduction in phytoplankton growth rates and biomass, suggesting that natural communities may be more sensitive than cultured algae.
\end{abstract}

KEY WORDS: Phytoplankton Bacterioplankton Selenium · Biotransformation Lacustrine

\section{INTRODUCTION}

Selenium is present in aquatic ecosystems in a number of different chemical forms. Dissolved forms include the inorganic species, selenate and selenite, and the reduced and organic selenides. Elemental selenium may be present in colloidal form and is generally included in measurements of dissolved organic selenium species

Phytoplankton and bacterioplankton communities facilitate the uptake of dissolved selenium to higher trophic levels through the food web. With the discovery of reproductive failure in fish and waterfowl populations of some selenium-contaminated freshwater systems (e.g. Gillespie \& Baumann 1986, Ohlendorf et al. 1986), interest in biological selenium incorporation and biologically mediated selenium transformations has increased. Because the transformations between chemical forms of selenium can be biologically mediated (e.g. Wrench 1978, Foda et al. 1983, Bottino et al.

\footnotetext{
·E-mail: friedel@acnatsci.org
}

1984, Cooke \& Bruland 1987, Vandermeulen \& Foda 1988, Oremland et al. 1989, 1990), the planktonic community may play a role in the transformation of selenium from one chemical form to another in aquatic systems.

Selenium is both essential for phytoplankton growth at low levels and toxic at high levels (Lindstrom \& Rodhe 1978, Lindstrom 1980, 1983, Wheeler et al. 1982, Wehr \& Brown 1985, Foe \& Knight 1986, Price et al. 1987, Ishimaru et al. 1989, Kiffney \& Knight 1990). In monospecific culture experiments, the difference between necessary and toxic levels of selenium is usually quite large. In an ecosystem containing several different chemical forms of selenium and a community composed of many different species with differing requirements and sensitivities, the levels of sufficiency and toxicity may be difficult to define.

As part of a larger, integrated experimental/modeling study of selenium transport, transformation, and impact in freshwater systems (Bowie \& Grieb 1991, Porcella et al. 1991), we performed experiments with natural phytoplankton and microbial communities from Hyco Lake, a man-made cooling reservoir for a 
coal-fired electric power plant in northern piedmont North Carolina, USA, with a history of selenium (selen.ite) contamination and declines in fish populations (Cumbie \& Van Horn 1978, Gillespie \& Baumann 1986, Ogle et al. 1988, Cutter 1991).

Total dissolved selenium levels within Hyco Lake have varied through time, but ranged from 38 to $200 \mathrm{nM}$ in the late $1980 \mathrm{~s}$, predominantly in the form of selenite (Cutter 1991). Since a change in fly ash handling procedures in 1990 significantly reduced selenium inputs (B. Ward, Carolina Power and Light, pers. comm.), selenium concentrations have dropped, with concentrations from $<13$ to $38 \mathrm{nM}$, but are still much higher than in most uncontaminated freshwaters (Cutter 1989).

lin oui experiments, natural phrtoplankton and microbial communities were collected from the lake and challenged with elevated levels of selenate and selenite to evaluate the rate of selenium uptake, transformation, and impact in these communities.

The goals of these experiments were to:

(1) Provide basic rate data on the uptake of selenium by natural phyto- and bacterioplankton for the modeling effort (see Bowie \& Grieb 1991, Porcella et al. 1991).

(2) Quantify the role of phytoplankton and bacterioplankton in the transformations of selenium between different dissolved forms.

(3) Determine whether elevated concentrations of selenium found in some freshwater systems had significant effects on the growth rate or composition of plankton.

\section{MATERIALS AND METHODS}

Sampling. Two stations were located within Hyco Lake in October 1991. One station, hereby designated the 'south arm', was located in the shallow southern arm of the lake, at a depth of $1 \mathrm{~m}$. This arm of the lake receives the majority of runoff, and is less contaminated with selenium than the rest of the lake (Cutter 1991). The second station, the 'plant site', was located in the central region of the lake close to the electric generating plant and the ash pond discharge, at $12 \mathrm{~m}$ depth. Temperature, dissolved oxygen, and $\mathrm{pH}$ were determined in situ using conventional probes. Samples were collected in the field to determine dissolved nutrient (nitrate, nitrite, ammonium, phosphate, silicate) concentrations, particulate carbon and nitrogen, chlorophyll $a$, and phytoplankton and zooplankton density (Table 1).

Originally, the objective for choosing these 2 stations for experimentation was to examine whether there were significant differences in selenium uptake, trans- formation and effect between these stations due to the differences in exposure to selenium contamination However, the differences between these stations were relatively minor (the south allin station had higher nitrate, silicate, particulate carbon and nitrogen, phytoplankton and bacterioplankton densities than the plant site), and the stations had similar uptake and responses to selenium additions. Therefore, with minor exceptions, we will present data from the south arm station only.

Nutrients were analyzed by standard autoanalyzer techniques, particulate carbon and nitrogen by dry combustion/infra-red $\mathrm{CO}_{2}$ analysis (Strickland \& Parsons 1972), chlorophyll by acetone extraction/spectrophotometric analysis (Strickland \& Parsons 1972). Phytoplankton samples were preserved (Utermöhl 1958), settled and counted by inverted microscopy. Bacterial densities were determined by acridine orange direct counting (Hobbie et al. 1977). Bacteria size distributions were determined using an optical micrometer (the average cell diameter of bacterial cells in ambient Hyco Lake water at the time of collection was $0.47 \pm 0.17 \mu \mathrm{m}$ )

In addition, $140 \mathrm{l}$ of water was collected from the south arm station, and 60 I from the plant site, by dipping $20 \mathrm{l}$ acid-washed (Boyle \& Huested 1983) polyethylene carboys just below the surface. This water was returned to the laboratory, where samples were taken for selenium concentration and speciation (Table 1), and the biological studies described below.

From each station, 20 i of water was screened through acid-cleaned $35 \mu \mathrm{m}$ nylon mesh to remove large grazers, to be used in the short-term uptake and long-term growth and transformation experiments

Table 1. Background water quality parameters in the experimental water coljected from Hyco Lake, N. Carolina, USA

\begin{tabular}{|lcc|}
\hline Parameter & South arm & Plant site \\
\hline Nitrite $(\mu \mathrm{M})$ & 1.5 & 2.0 \\
Nitrate $(\mu \mathrm{M})$ & 41 & 7.5 \\
Ammonium $(\mu \mathrm{M})$ & 6.0 & 7.6 \\
Phosphate $(\mu \mathrm{M})$ & 0.13 & 0.17 \\
Silicate $(\mu \mathrm{M})$ & 19.6 & 13.5 \\
Particulate C $(\mu \mathrm{M})$ & 99.9 & 22.5 \\
Particulate $\mathrm{N}(\mu \mathrm{M})$ & 15.7 & 2.9 \\
Chlorophyll a $\left(\mu \mathrm{g} \mathrm{l^{-1 }}\right)$ & 17.9 & 6.99 \\
Dissolved oxygen $(\mu \mathrm{M})$ & 222 & 208 \\
pH & 6.65 & 6.74 \\
Temperature $\left({ }^{\circ} \mathrm{C}\right)$ & 20.0 & 24.5 \\
Selenium $(\mathrm{nM})$ & & \\
Selenite & 6.7 & 16.6 \\
Selenate & 0.4 & 1.9 \\
Organic + elemental & 6.5 & 4.7 \\
Phytoplankton $\left(10^{6} \mathrm{cells}^{-1}\right)$ & 20.5 & 8.8 \\
Bacterioplankton $\left(10^{9}\right.$ cells $\left.{ }^{-1}\right)$ & 11.2 & 6.8 \\
\hline
\end{tabular}


described below. Samples collected before and after screening contained the same phytoplankton cell densities and dominant species within counting error

Selenium analysis. Water samples taken for selenium analysis were filtered through acid-cleaned (25\% HCl) Whatman GF/F filters, placed in cleaned HDPE bottles, acidified to $0.2 \%$ with Baker trace metal-grade $\mathrm{HCl}$ and refrigerated until analyzed. Samples were analyzed by hydride generation, standardized against additions of selenite (Cutter 1978, 1983). Selenite was analyzed directly in $4 \mathrm{~N} \mathrm{HCl}$ (Baker trace metal grade), while selenate+selenite concentration was determined after digestion in $4 \mathrm{~N} \mathrm{HCl}$, and total dissolved selenium was determined after digestions with $\mathrm{K}_{2} \mathrm{~S}_{2} \mathrm{O}_{8}$ in $4 \mathrm{~N} \mathrm{HCl}$ (Cutter \& Bruland 1984). Selenate and organic selenium concentrations were calculated by difference. Using a maximum sample size of $40 \mathrm{ml}$, minimum detectable concentrations were approximately $0.06 \mathrm{nM}$ for selenite, $0.1 \mathrm{nM}$ for selenate, and 0.2 nM for organic and elemental selenium. With samples from the long-term cultures grown with added inorganic selenium, organic selenium forms were separated and concentrated using reverse-phase C-18 resins, digested and measured using the total selenium technique (Cooke \& Bruland 1987). This method separates only the more hydrophobic fraction of the organic selenium compounds present, but is a direct measurement, unlike the above measurement for organic and elemental forms by difference. Determination of organic selenium by difference is less precise in the presence of relatively large amounts of added inorganic selenium.

Accumulation of selenite and selenate by particles from Hyco Lake. For short-term selenium accumulation studies, duplicate $250 \mathrm{ml}$ samples of $35 \mu \mathrm{m}$ screened water from each station received either $127 \mathrm{nM}^{75}$ Se-labeled selenite or selenate. ${ }^{75}$ Se-labeled selenite and selenate were obtained from Amersham Corp., with specific activities of $1.22 \times 10^{5}$ and $7.59 \times$ $10^{3} \mathrm{GBq} \mathrm{mol}^{-1}$ respectively. The selenite stock was diluted to $1.22 \times 10^{4} \mathrm{GBq} \mathrm{mol}^{-1}$ with sodium selenite (Alfa Chemicals) for use in this study. The water samples were incubated for $24 \mathrm{~h}$ at $22^{\circ} \mathrm{C}$ at a light intensity of approximately $100 \mu$ Ein $\mathrm{m}^{-2} \mathrm{~s}^{-1}$, with a $12: 12 \mathrm{~h}$ light:dark cycle, and sampled at $0,2,6,12$, and $24 \mathrm{~h}$. At each sampling, $10 \mathrm{ml}$ aliquots were filtered through $0.2,0.4,0.8,3$, and $8 \mu \mathrm{m}$ pore size polycarbonate filters to size-fractionate selenium accumulation. The filters were rinsed with three $5 \mathrm{ml}$ portions of unlabeled artificial freshwater medium. The ${ }^{75} \mathrm{Se}$ activity on the filters was then determined by gamma spectrometry (Riedel et al. 1991).

Selenium concentration-dependent accumulation rates were measured using the same screened phytoplankton communities in a similar manner for both selenite and selenate. Samples of the screened water $(25 \mathrm{ml})$ from each station were incubated as above for $6 \mathrm{~h}$ with ${ }^{75}$ Se selenate and selenite additions from 12.7 to $633 \mathrm{nM}$. The samples were filtered through $1.0 \mu \mathrm{m}$ polycarbonate filters, rinsed 3 times, and were counted as above

Impact and transformation of selenium in natural microbial communities. The remaining 120 l of water from the south arm station was filtered through Gelman A/E glass fiber filters (nominal pore size $1 \mu \mathrm{m}$ ) to remove phytoplankton and larger particles, amended with nutrients $(10 \mu \mathrm{M}$ phosphate, $50 \mu \mathrm{M}$ nitrate and silicate), and used as culture medium for longer-term studies of selenium uptake, transformation, and effect. This medium (3.0 l) was placed in nine 4 l acid-cleaned polyethylene Cubitainers ${ }^{(}$; each received $300 \mathrm{ml}$ of $35 \mu \mathrm{m}$ screened water from the south arm as a phytoplankton inoculum. Triplicate cubitainers received either no added selenium, or additions of $127 \mathrm{nM}$ selenate or selenite, and were placed in an outdoor raceway where they were maintained for $14 \mathrm{~d}$ under ambient light and temperature (temperature range: 18 to $21^{\circ} \mathrm{C}$ over the course of the experiment, similar to temperatures at the collection sites at the time of collection; Table 1). The technique follows the biological and chemical processes that occur during the development of a phytoplankton bloom: the lag phase before the bloom occurs, the peak growth period, and the bloom's decline (Sanders \& Riedel 1993).

Samples were taken daily for measurement of in vivo fluorescence, a rapid measure of phytoplankton biomass (Goldman et al. 1973, D'Elia et al. 1986). Samples were taken 5 times during the course of the experiment for selenium concentration and speciation, and 4 times for bacterial density and phytoplankton cell density and species composition.

Bacterial biomass was estimated using the average cell size at the time of water collection, and the assumption that cells averaged $10^{-15} \mathrm{~mol} \mathrm{C} \mathrm{mm}^{-3}$ (Watson et al. 1977). This estimate for $C$ per cell is based on the relatively large average measured size of cells in Hyco Lake, and the decrease in biomass to biovolume ratio with increasing cell size (Lee \& Fuhrman 1987).

On 3 days, the short-term ( $1 \mathrm{~h}$ ) uptake rate of selenate was examined in 3 size fractions, $>3,0.8-3$, and $0.2-0.8 \mu \mathrm{m}$. Subsamples $(10 \mathrm{ml})$ from each of the $3 \mathrm{cu}$ bitainers per treatment were combined for the uptake experiments. These subsamples received an additional $127 \mathrm{nM}$ selenate as ${ }^{75} \mathrm{SeO}_{4}$ and were incubated for $1 \mathrm{~h}$ under ambient midday temperature and light conditions. Separate aliquots were then filtered onto $3,0.8$ and $0.2 \mu \mathrm{m}$ polycarbonate filters, and subsequently rinsed twice with $5 \mathrm{ml}$ of an artificial freshwater growth medium with no added selenium. The ${ }^{75}$ Se activity on the filters was assayed by gamma spectrometry. 
Selenium inhibition of natural phytoplankton communities. Because of apparent inhibition of phytoplankton growth by $127 \mathrm{nM}$ added selenate in the long-term growth and transformation experiment (see 'Results'), a second phytoplankton growth experiment with natural phytoplankton was carried out to further examine the effect of selenate and selenite on phytoplankton growth. Water was collected in November 1991 at the south arm station, brought to the laboratory, and screened as above. The phytoplankton cultures were amended with $10 \mu \mathrm{M}$ phosphate, $50 \mu \mathrm{M}$ nitrate and silicate, placed in $50 \mathrm{ml}$ test tubes, and received a series of selenate and selenite supplements $(0,127,317,633,1266$, and $2533 \mathrm{nM})$ in duplicate. The cultures were incubated indoors at $21^{\circ} \mathrm{C}$ and a light initensity of approximatcly $100 \mu$ Fin $\mathrm{m}^{-2} \mathrm{~s}^{-1}$, with a 12:12 h light:dark cycle. Phytoplankton growth was monitored daily by in vivo fluorescence. The cells were preserved in Utermöhl's solution at the end of the experiment for enumeration of phytoplankton, settled and counted by inverted microscopy.

\section{RESULTS}

\section{Short-term selenium accumulation}

\section{Selenite}

Total selenite incorporated by particles $>0.2 \mu \mathrm{m}$ in the water samples from the south arm exposed to an addition of $127 \mathrm{nM}$ selenite increased steadily through the $24 \mathrm{~h}$ incubation (with the exception of the $>8 \mu \mathrm{m}$ fraction), averaging $41.4 \mathrm{pmol} \mathrm{Se} \mathrm{l}^{-1} \mathrm{~h}^{-1}$ overall (Fig. 1). Selenium incorporation rates were also approximately linear in time at the plant site, but at a lower average rate, $7.47 \mathrm{pmol} \mathrm{Se}^{-1} \mathrm{~h}^{-1}$. When normalized to biomass (either carbon or chlorophyll a), however, rates were similar. Uptake averaged $360 \mathrm{nmol}$ Se $(\mathrm{mol} \mathrm{C})^{-1} \mathrm{~h}^{-1}$ from the south arm station and $265 \mathrm{nmol} \mathrm{Se}(\mathrm{mol} \mathrm{C})^{-1}$ $\mathrm{h}^{-1}$ from the plant site (Table 2 ). The majority of the selenium incorporated ( 75 to $90 \%$ ) was found to be associated with particles greater than $0.8 \mu \mathrm{m}$ in size (Fig. 2). Selenite uptake rates were also proportional to selenite concentration (Fig. 3). When normalized to biomass (carbon or chlorophyll a), the stations again exhibited similar average concentration-dependent uptake rates.

\section{Selenate}

Selenate incorporation was more linear over time than for selenite, but rates of uptake over $24 \mathrm{~h}$ were 21 to $25 \%$ of the selenite uptake rate (Fig. 1). As with selenite, averaged hourly rates of uptake were lower in particles from the plant site than from the south arm station, but were much closer when normalized to phytoplankton biomass (Table 2). Most ( 81 to $82 \%$ ) of the incorporation occurred with particles larger than $0.8 \mu \mathrm{m}$, but in a smaller size class than selenite (Fig. 2). Uptake also increased linearly with selenate concentration in the medium (Fig 3).

\section{Long-term impacts and transiormations of selenium}

\section{Phytoplankton and bacterial growth}

Phytoplankton inoculated into filtered water from the south arm station with and without added selenate and selenite reached a peak in biomass after $9 \mathrm{~d}$ (Fig. 4). Selenate additions of $127 \mathrm{nM}$ reduced overall phytoplankton growth rates and peak biomass slightly (Fig. 4). These reductions were statistically significant $(p<0.05,1$-way ANOVA). Biomass remained lower in selenate-dosed cultures relative to controls until after it peaked on Day 9. Results with the inoculum from the plant site were virtually identical.

The phytoplankton community from the south arm station was initially dominated by 3 species, a chlorophyte (Ankistrodesmus sp.) a cyanophyte (Merismope-
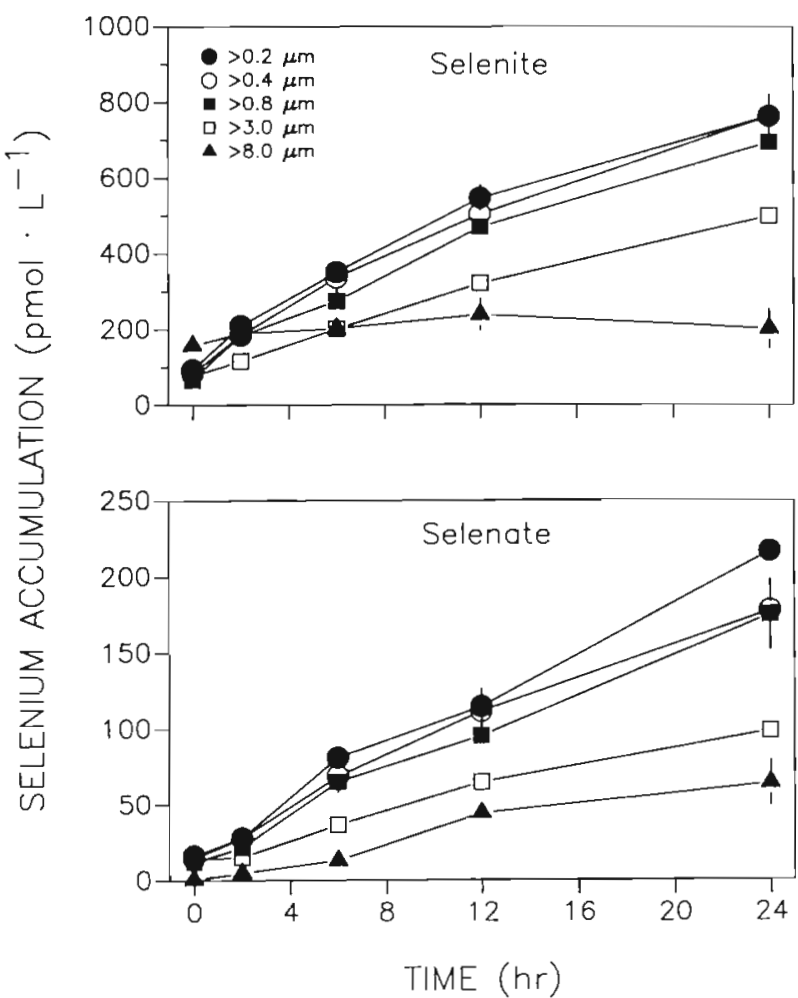

Fig. 1. Short-term selenium accumulation by particles retained on filters of different pore size from south arm station over time. Error bars are $\pm \operatorname{SE}(n=2)$ 
Table 2. Selenium uptake in short-term $(24 \mathrm{~h})$ time course experiments. Total material retaned by $0.2 \mu \mathrm{m}$ filter, normalized to particulate carbon and chlorophyll

\begin{tabular}{|c|c|c|c|c|}
\hline Station & Treatment & pmol l $^{-1} h^{-1}$ & $\begin{array}{c}\text { Average Se uptake ra } \\
\mu \mathrm{mol}(\mathrm{mol} \mathrm{C})^{-1} \mathrm{~h}^{-1}\end{array}$ & $\mu$ mol $\left(\mathrm{g} \mathrm{chl} \mathrm{a}^{-1} \mathrm{~h}^{-1}\right.$ \\
\hline \multirow[t]{2}{*}{ South arm } & Selenite & 41.4 & 0.360 & 2.02 \\
\hline & Selenate & 8.7 & 0.076 & 0.43 \\
\hline \multirow[t]{2}{*}{ Plant site } & Selenite & 7.5 & 0.265 & 2.41 \\
\hline & Selenate & 1.8 & 0.062 & 0.58 \\
\hline
\end{tabular}

\section{Selenate accumulation rates by microbial communities}

On Day 3 of the long-term experiment, the uptake rate of selenate by particles in the control cubitainers (Fig 5) was $19.0 \mathrm{pmol} \mathrm{l}^{-1} \mathrm{~h}^{-1}$, slightly higher than uptake rates in untreated lake water (Table 2). By Day 6 uptake rates averaged across all treatments were about 20 times higher than on Day 3; phytoplankton biomass had dia sp.) and an unidentified monad. These 3 species accounted for more than $75 \%$ of total cell density. By Day 9 these species had been replaced by new dominants, an unidentified chlorophyte, the chlorophyte Dictyosphaerium sp., and a pennate diatom (Fragilaria $\mathrm{sp}$.); but chlorophytes remained the dominant taxon, at $83 \%$ of the total. No effect of selenium additions on the resulting phytoplankton communities was observed.

Bacterial densities declined during the logarithmic phase of phytoplankton growth, then rose when phytoplankton growth slowed, reaching greatest densities after the phytoplankton had begun to decline (Fig. 4). No effects of selenate or selenite additions on bacterial density were observed.

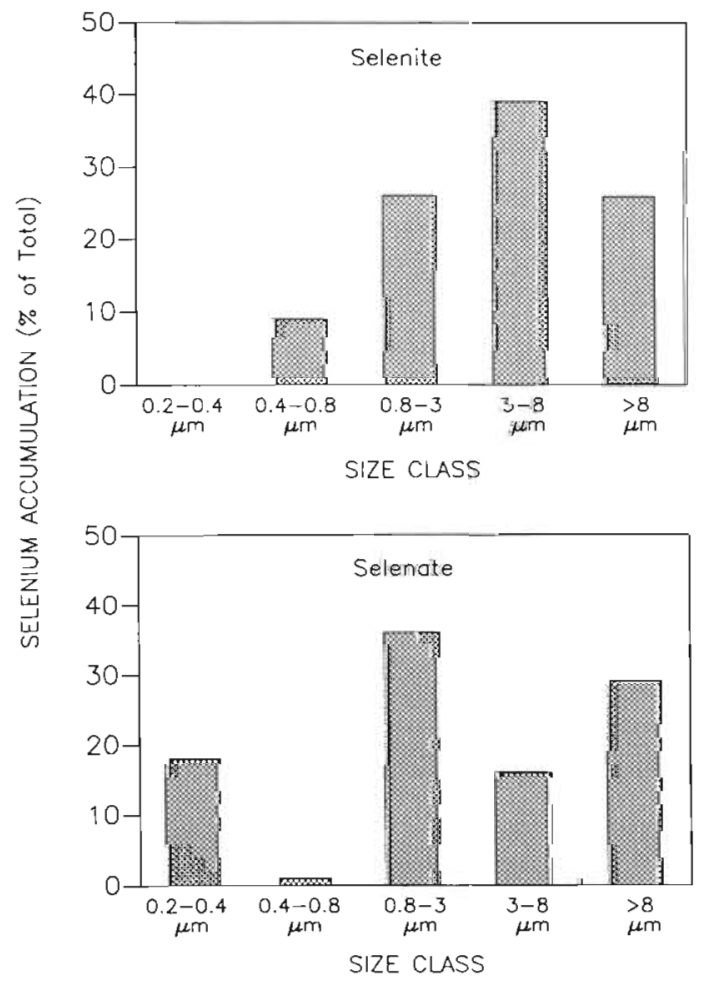

Fig. 2. Short-term ( $24 \mathrm{~h}$ ) selenium accumulation by south arm station particles of various size fractions expressed as the percent of uptake of the total accumulation retained by a $0.2 \mu \mathrm{m}$ filter also increased by about a factor of 10 during that time (Fig. 4). By Day 10, the average selenate uptake had declined, as had the biomass of phytoplankton. The pattern of selenate uptake followed the pattern of biomass, although selenate uptake rates increased more than did biomass.

The distribution of selenate uptake among size classes of particles also changed over the course of the long-term incubations (Table 3, Fig. 5). When phytoplankton were in logarithmic growth phase (Day 3), most of the selenium accumulation ( $>75 \%$ ) was into the $>3 \mu \mathrm{m}$ size fraction, where phytoplankton predominate. However, as the phytoplankton came into stationary phase and biomass declined (Day 10), a large $(>80 \%)$ portion of total short-term selenate accumulation occurred in the smallest size fraction, $0.2-0.8 \mu \mathrm{m}$, which is dominated by bacterioplankton.

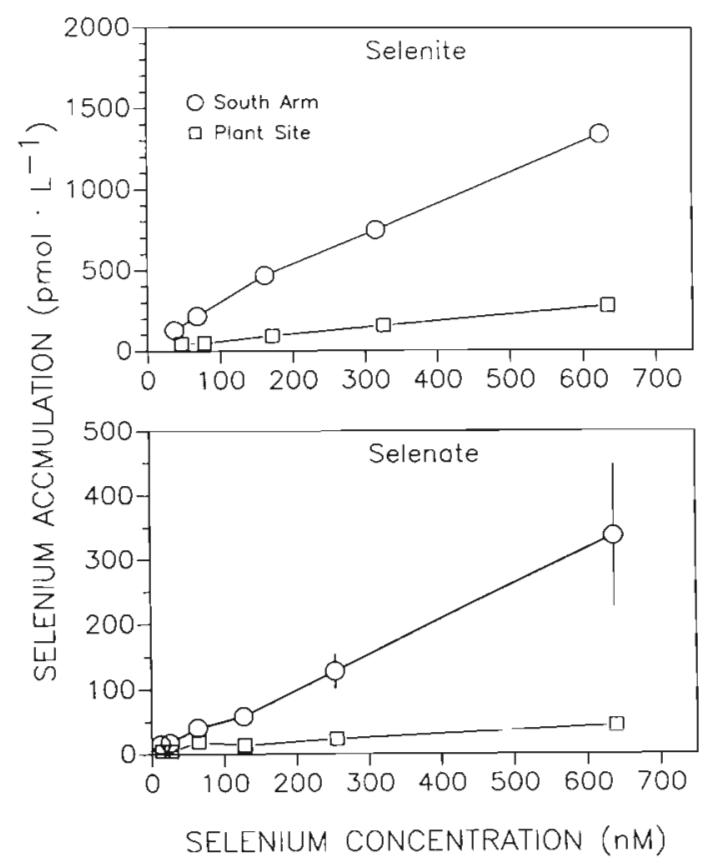

Fig 3. Concentration dependence of short-term $(6 \mathrm{~h})$ selenium accumulation by particles retained by a $1.0 \mu \mathrm{m}$ filter from the 2 experimental sites exposed to varying concentrations of selenate or selenite. Error bars are $\pm \operatorname{SE}(n=2)$ 


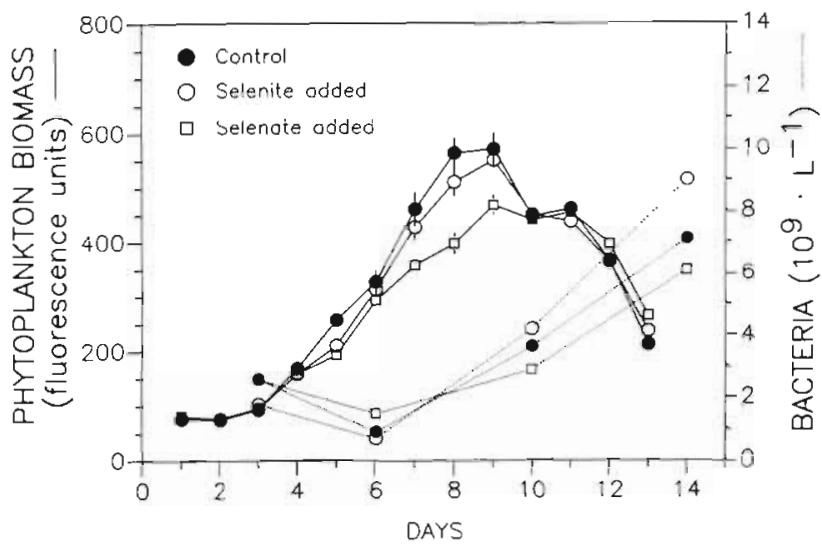

Fig. 4. Phytoplankton biomass (in vivo fluorescence) and bacteridi densiiy is water fiom the south arm station cultured with no selenium addition (control), 127 nM selenate additions or $127 \mathrm{nM}$ selenite additions. Mean $\pm \mathrm{SE}$

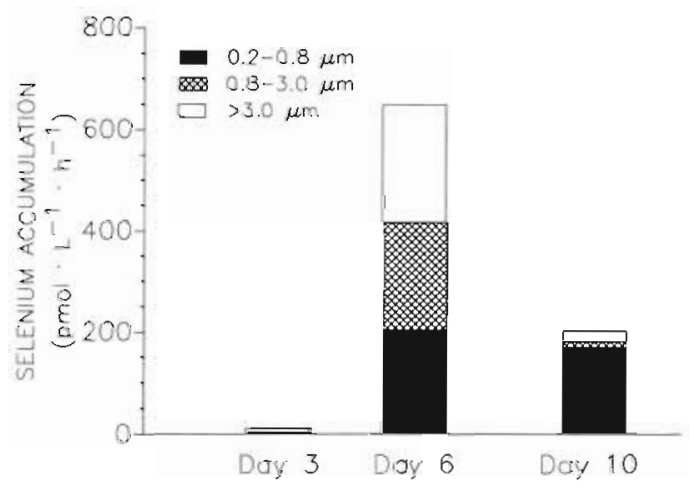

Fig. 5. Short-term selenate uptake rates into 3 size classes of particles during the long-term growth experiment. Uptake rates were measured over $1 \mathrm{~h}$ in subsamples from the no selenium addition treatment, using $127 \mathrm{nM}$ additional selenate added as ${ }^{75} \mathrm{SeO}_{4}$

Normalized to biomass (carbon), uptake rates by bacterioplankton- and phytoplankton-sized particles were very different, and varied with the growth phase of cells (Table 3 ). Biomass-normalized selenate uptake rates were similar for bacterioplankton and phytoplankton on Day 3, at which time phytoplankton were in log-phase growth and bacteria densities were in decline (Figs, $4 \& 5$ ). However, on Day 6 , at the beginning of rapid bacterial growth, and on Day 10, when bacterioplankton were still increasing in number, but phytoplankton were declining, the uptake rate of selenium per $\mathrm{g}$ carbon was about 10 times greater by bacterioplanktonsized particles than by phytoplanktonsized particles. In both size classes. uptake rates per $\mathrm{g} \mathrm{C}$ increased dramatically during rapid growth phases.

\section{Selenium transformation during the long-term experiment}

The measured concentration and speciation of dissolved selenium varied little during the long-term experiment. Total dissolved selenium did not vary greatly during the experiment, and averaged $12.7 \pm 0.6$ $\mathrm{nM}$ (mean $\pm \mathrm{SE}$ ) in controls and $133 \pm 0.5 \mathrm{nM}$ in selenate and selenite-dosed assemblages. The concentration of dissolved selenite increased significantly through time in cultures from both stations dosed with selenate (Fig 6). yielding averaged selenite production rates of $0.57 \mathrm{nmol} \mathrm{l}^{-1} \mathrm{~d}^{-1}$, but not significantly in control assemblages. Organic selenium concentrations (as measured by concentration on C-18 resin) averaged $1.65 \pm 0.13 \mathrm{nM}$ at the end of the experiment, regardless of treatment or station.

\section{Selenate and selenite inhibition of growth}

When phytoplankton growth experiments were repeated in November, with a wider range of selenate and selenite concentrations, selenate again inhibited growth while selenite did not. Growth rates were similar to those seen in the outdoor experiment, with control assemblages averaging 0.63 doublings $\mathrm{d}^{-1}$ over the first $3 \mathrm{~d}$ of growth. Selenite concentrations as high as $2533 \mathrm{nM}$ did not affect assemblage growth rates, but selenate concentrations of $317 \mathrm{nM}$ and above significantly reduced growth $(p<0.05$; Fig. 7 ). The phytoplankton assemblage was again dominated by Ankistrodesmus sp., Dictyosphaerium sp., and an unidentified monad; as in the outdoor experiments, species dominance was not affected by selenate-induced reductions in overall growth rate.

Table 3. Distribution of biomass and percent selenate uptake between bacterioplankton and phytoplankton during the incubation experiment; and short-term $(1 \mathrm{~h})$ selenate uptake rates by bacterioplankton and phytoplankton normalized to the biomass in each size class (mean \pm SD). Bacterioplankton were defined as cells between 0.2 and $0.8 \mu \mathrm{m}$ diameter, phytoplankton as $>0.8 \mu \mathrm{m}$, based on an average bacterial cell diameter of $0.47 \pm 0.17 \mu \mathrm{m}$

\begin{tabular}{|lccc|}
\hline & \multicolumn{3}{c|}{ Days at incubation: } \\
& 3 & 6 & 10 \\
\hline Se uptake $\left(\mu \mathrm{mol}\right.$ Se $\left.\mathrm{mol}^{-1} \mathrm{C} \mathrm{h}^{-1}\right)$ & & & \\
Bacterioplankton $(0.2-0.8 \mu \mathrm{m})$ & $0.44 \pm 0.68$ & $25.9 \pm 41.0$ & $10.9 \pm 9.0$ \\
Phytoplankton $(>0.8 \mu \mathrm{m})$ & $0.41 \pm 0.21$ & $2.3 \pm 2.4$ & $0.76 \pm 0.55$ \\
$\%$ biomass as bacterioplankton & $19 \pm 5.0$ & $3.7 \pm 1.1$ & $7.2 \pm 1.4$ \\
$\%$ Se uptake by bacterioplankton & $18 \pm 21$ & $28 \pm 21$ & $51 \pm 3$. \\
\hline
\end{tabular}




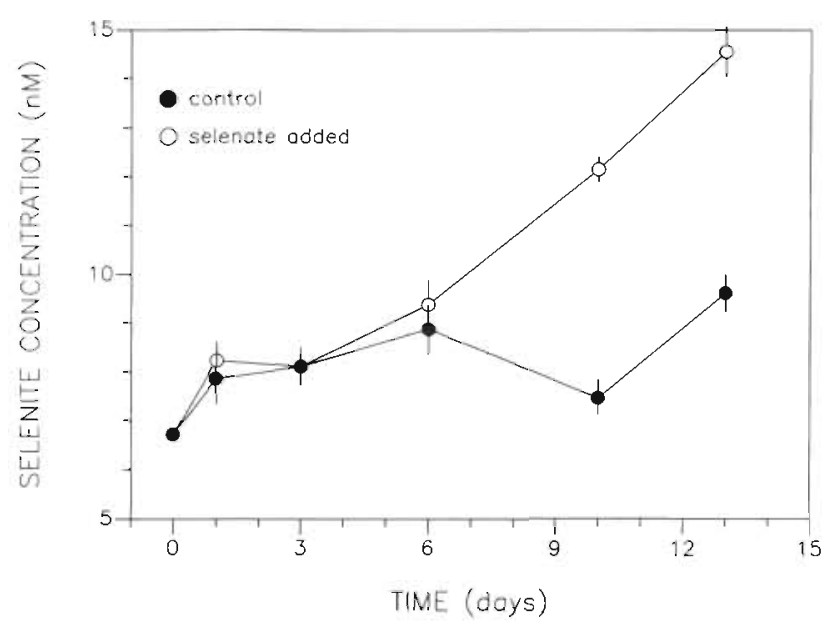

Fig. 6. Increase in selenite concentration over time in longterm control and selenate-dosed phytoplankton assemblages $($ mean $\pm \mathrm{SE})$

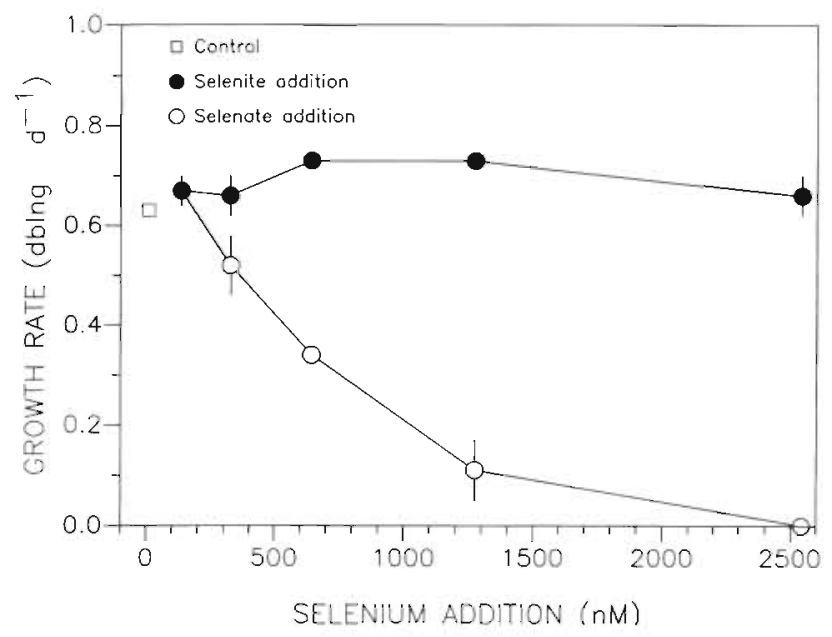

Fig. 7. Growth rate (doublings $d^{-1}$ ) of phytoplankton from the south arm station grown with a range of selenate and selenite additions. Mean $\pm \mathrm{SE}(\mathrm{n}=3)$

\section{DISCUSSION}

\section{Selenium uptake and incorporation}

The selenium content of particles $>0.2 \mu \mathrm{m}$ from $\mathrm{Hyco}$ Lake increased over the time course examined (24 h), was proportional to concentration in the medium up to $633 \mathrm{nM}$, and was proportional to biomass (carbon or chlorophyll). As has been shown in previous studies (Wheeler et al. 1982, Wrench \& Measures 1982, Lindstrom 1983, Riedel et al. 1991), short-term selenite uptake rates in these experiments were 4 to 5 times faster than selenate uptake rates (e.g. Table 2, Figs. 1 \& 3). With selenite, initial uptake rates were more rapid than rates over the longer term; some lessening of uptake rate, for example, was seen (Fig. 1), particularly after the first $12 \mathrm{~h}$. A substantial portion of initial selenite uptake appears to occur by passive sorption to cell and particle surfaces over the first few hours, as indicated by uptake by heat-killed cells (Riedel et al 1991)

The relative importance of various size classes of cells for selenium uptake was dependent on both the distribution of biomass among size classes and the relative growth phase of the organisms. In the unaltered lake water examined, phytoplankton dominated both biomass and selenium uptake. In the long-term incubation experiment, phytoplankton (cells $>0.8 \mu \mathrm{m}$ ) dominated selenate uptake until they reached stationary phase, after which time bacterial growth increased and selenate uptake was predominantly by particles $<0.8 \mu \mathrm{m}$. The pattern of increasing selenate uptake by bacterioplankton as phytoplankton come into stationary phase suggests that selenate uptake is a function of cell activity as well as biomass. Normalized to biomass, selenate uptake increased when cell growth rates increased, both for bacterioplankton and phytoplankton. In their rapid growth phase in the enrichment cultures, bacterioplankton took up much more selenate per unit carbon than did larger cells. This may be a function of the greater surface to volume ratios or greater relative metabolic rates.

Phytoplankton and bacterioplankton provide an excellent vehicle for selenium uptake and subsequent incorporation into higher trophic levels (Sandholm et al. 1973, Zhang et al. 1990, Sanders \& Gilmour 1994). In fact, assimilation of selenium from food is greater than for most other trace elements (Fowler \& Benayoun 1976, Reinfelder \& Fisher 1991, Luoma et al. 1992) However, the uptake, incorporation and transformation of dissolved selenium by phytoplankton and bacteria are not the sole processes involved in the uptake and transformations of selenium in aquatic systems Other uptake and transformation mechanisms [e.g direct uptake of dissolved selenium by higher organisms (Bertram \& Brooks 1986, Luoma et al. 1992), particle sorption (Balistrieri \& Chao 1990), and reduction to elemental selenium in anoxic waters or sediments (Cutter 1989, 1991, Oremland et al. 1989, 1990)] may be of equal or greater importance to selenium bioaccumulation.

\section{Selenium transformation}

Only minor transformation of dissolved selenium occurred during these experiments. The only statistically significant change was the increase in selenite in selenate-dosed assemblages, presumably from biological uptake of selenate, and subsequent reduction and 
release. The increase of selenite was slow, less than $0.5 \% \mathrm{~d}^{-1}$. Selenite concentrations in the selenate treatment became significantly different from the control treatments by Day 10, after the phytoplankton biomass peak, and after the rebound of bacterial abundance.

No measurable changes in dissolved organic selenium as measured by $\mathrm{C}-18$ separation were noted over the $2 \mathrm{wk}$ period. Concentrations averaged $1.65 \mathrm{mM}$ at the beginning and near the end of the experiment, with no effect of treatment or time noted. Natural systems often are dominated by organic selenium, and it has been presumed that the source is biological uptake and transformation of inorganic selenium (Cutter 1989). A longer time course may be required to accurately measure the production of such compounds in natural phytoplankton assemblages.

\section{Selenium toxicity}

The growth reduction noted in this study, 17 to $25 \%$ at a selenate concentration $127 n \mathrm{nM}$ above ambient levels in one experiment and $18 \%$ at $317 \mathrm{nM}$ in another, was large enough to reduce cell density by 17 to $35 \%$ at the time of peak cell density. Our results, and those reported earlier (e.g. Kumar \& Prakish 1971, Wheeler et al. 1982, Kiffney \& Knight 1990), indicate that selenate is generally more toxic to phytoplankton than selenite. Within Hyco Lake, where selenium is predominantly selenite, reductions in phytoplankton growth due to the toxicity of selenate are not likely. However, other systems are (or have been) exposed to elevated selenate concentrations (e.g. Kesterson Reservoir and other agricultural drainage systems in the western United States), although growth reductions in phytoplankton have not been reported. It is possible that a closer examination of natural phytoplankton in other natural systems would exhibit higher sensitivities to selenate than have been seen in the laboratory.

To our knowledge, this study is the first to examine selenium effects on a natural plankton community, and the levels of selenium required to reduce phytoplankton growth rate in these studies are lower than most published accounts using cultured species (Kumar \& Prakish 1971, Wheeler et al. 1982, Bennett 1988, Kiffney \& Knight 1990).

\section{CONCLUSIONS}

Selenium was actively incorporated by phyto- and bacterioplankton from a lake with historical selenium contamination. Size-fractionated selenium uptake measurements on unaltered lake water have shown that both selenite and selenate were taken up by the phytoplankton/bacterioplankton community at rates proportional to biomass, with the majority of uptake taking place by phytoplankton-size particles $(>0.8 \mu \mathrm{m})$. In enrichment cultures, however, selenate uptake was initially dominated by phytoplanktonsized particles during their logarithmic growth phase, and later dominated by bacteria-sized particles $(<0.8 \mu \mathrm{m})$ during the subsequent phytoplankton senescent phase when bacterial abundances increased, suggesting that uptake is a function of cellular activity as well as biomass.

In addition to uptake by cells, some transformation of the chemical form of selenium was observed. Selenite concentrations increased slowly but significantly in the iong-term cuitures wiih adued seieriate. The production of selenite occurred after the phytoplankton logarithmic growth phase, during their senescent phase, suggesting that bacteria were responsible. No selenate or organic selenium production was observed. Taken together, these studies provide rate clata for the transfer of dissolved selenium into the base of aquatic food webs and the transformation of dissolved selenate to selenite.

Growth of natural phytoplankton from the lake was inhibited by selenate concentrations of $127 \mathrm{nM}$, levels below previously reported inhibitory levels using laboratory cultures. Inhibition by selenite was not observed. The species composition of the inhibited cultures was not different from the controls. No evidence for inhibition of bacterial growth was observed.

Acknowledgements. We thank D. Ferrier and K. Gloersen for assistance in sampling and field aspects, D. Ferrier, D. Connell, G. S. Riedel, S. Sellner and L. Cole for laboratory assistance, and R. Sanders for comments on the manuscript. This work was supported by the Electric Power Research Institute under Project RP2020-11

\section{LITERATURE CITED}

Balistrieri LS, Chao TT (1990) Adsorption of selenium by amorphous iron hydroxide and manganese dioxide. Geochım Cosmochim Acta 54:739-751

Bennett WN (1988) Assessment of selenium toxicity in algae using turbidostat culture. Wat Res 22:939-942

Bertram PE, Brooks AS (1986) Kinetics of accumulation of selenium from food and water by fathead minnows. Wat Res 20:877-884

Bottino NR, Banks $\mathrm{CH}$, Irgolic KJ, Meeks P, Wheeler AE, Zingaro RA (1984) Selenium-containing amino acids and proteins in marine algae. Phytochemistry 23:2445-2450

Bowie GL, Grieb TM (1991) A model framework for assessing the effects of selenium on aquatic ecosystems. Water Air Soll Pollut 57/58:13-22

Boyle EA, Huested S (1983) Aspects of the surface distributions of copper, nickel, cadmium, and lead in the North Atlantic and North Pacific. In: Wong CS, Boyle EA, Burton 
JD, Goldberg ED (eds) Trace metals in seawater Plenum Press, New York, p 379-394

Cooke TD, Bruland KW (1987) Aquatic chemistry of selenium: evidence of biomethylation. Environ Sci Technol 21: $1214-1219$

Cumbie PM, Van Horn SL (1978) Selenıum accumulation associated with fish mortality and reproductive failure. Proc Ann Conf SE Assoc Fish Wild Agencies 32:612-624

Cutter GA (1978) Species determination of selenium in natural waters. Analyt Chım Acta 98:59-66

Cutter GA (1983) Elimination of nitrite interference in the determination of selenıum by hydride generation. Analyt Chim Acta 149:391-394

Cutter GA (1989) Freshwater systems. In: Ihnat M (ed) Occurrence and distribution of selenium. CRC Press, Inc, Boca Raton, p 243-262

Cutter GA (1991) Selenium biogeochemistry in reservoirs, Vol 1. Time series and mass balance results. Report to Electric Power Research Institute, EPRI EN-7281, Palo Alto, CA

Cutter GA, Bruland KW (1984) The marine biogeochemistry of selenium: a re-evaluation. Limnol Oceanogr 29:1179-1192

D'Elia CF, Sanders JG. Boynton WR (1986) Nutrient enrichment studies in a coastal plain estuary: phytoplankton growth in large-scale, continuous cultures. Can J Fish Aquat Sci 43:397-406

Foda A, Vandermeulen J, Wrench JJ (1983) Uptake and conversion of selenium by a marine bacterium. Can J Fish Aquat Sci 40:215-220

Foe C, Knight AW (1986) Selenium bioaccumulation, regulation, and toxicity in the green alga, Selenastrum capricornutum, and dietary toxicity of contaminated alga to Daphnia magna. In: Slocum LJ (ed) Selenium in the environment. California State University, Fresno, p 77-88

Fowler SW, Benayoun G (1976) Selenium kinetics in marine zooplankton. Mar Sci Commun 2:43-67

Gillespie RB, Baumann PC (1986) Effects of high tissue concentrations of selenium on reproduction by bluegills Trans Am Fish Soc 115:208-213

Goldman JC, Tenore KR, Stanley HI (1973) Inorganic nitrogen removal from wastewater effect on phytoplankton growth in coastal marine waters. Science 180:955-956

Hobbie JE, Daley RJ, Jasper S (1977) Use of Nuclepore filters for counting bacteria by fluorescence microscopy. Appl Environ Microbiol 33:1225-1228

Ishimaru T, Takeguchi T, Fukuyo Y, Kodama M (1989) The selenium requirement of Gymnodinium nagasakiense. In: Okaichi T, Anderson DM, Nemoto T (eds) Red tides: biology, environmental science and toxicology. Elsevier Science, New York, p 357-360

Kiffney P, Knight A (1990) The toxicity and bioaccumulation of selenate, selenite, and seleno-L-methionine in the cyanobacterium Anabaena flos-aquae. Arch Environ Contam Toxicol 19:488-494

Kumar HK, Prakish G (1971) Toxicity of selenium to the bluegreen algae Anacystis nidulans and Anabaena variabilis. Ann Bot 35:697-705

Lee S, Fuhrman J (1987) Relationships between biovolume and biomass of naturally derived marine bacterioplankton. Appl Environ Microbiol 53:1298-1303

Lindstrom K (1980) Peridinium cinctum bioassays of $\mathrm{Se}$ in Lake Arken. Arch Hydrobiol 82:110-117

Lindstrom K (1983) Selenium as a growth factor for planktonic algae in laboratory experiments and in some Swedish lakes. Hydrobiologia 101:35-48

Lindstrom K, Rodhe W (1978) Selenium as a micronutrient for the dinoflagellate Peridinium cinctum fa. westii. Mitt Int Ver Theor Angew Limnol 21:168-173
Luoma SN, Johns C, Fisher NS, Steinberg NA, Oremland RS, Reinfelder J (1992) Determination of selenium bioavailability to a benthic bivalve from particulate and solute pathways. Environ Sci Technol 26:485-491

Ogle RS, Maier KJ, Kiffney P, Willuams MJ, Brasher A, Melton LA, Knight AW (1988) Broaccumulation of selenium in aquatic ecosystems. Lake Reserv Manage 4:165-173

Ohlendorf HM, Hoffman DJ, Saiki MK, Aldnch TW (1986) Embryonic mortality and abnormalities of aquatic birds: apparent impacts of selenium from irrigation drain-water Sci Total Environ 52:49-63

Oremland RS, Hollıbaugh JT, Maest AS, Presser TS, Miller LG, Culberstson CW (1989) Selenate reduction to elemental selenium by anaerobic bacteria in sediments and culture: biogeochemical significance of a novel sulfate-independent process. Appl Environ Microbiol 55:2333-2343

Oremland RS, Steinberg NA, Maest AS, Miller LG, Hollibaugh JT (1990) Measurement of in situ rates of selenate removal by dissimulatory bacterial reduction in sediments. Environ Sci Technol 24:1157-1164

Porcella DB, Bowie GL, Sanders JG, Cutter GA (1991) Assessing Se cycling and toxicity in aquatic ecosystems. Water Air Soil Pollut 57-58:3-11

Price NM. Thompson PA, Harrison PJ (1987) Selenium: an essential element for growth of the coastal marine diatom Thalassiosira pseudonana (Bacillariophyceae). J Phycol 23:1-9

Reinfelder JR, Fisher NS (1991) The assimilation of elements ingested by marine copepods. Science 251:794-796

Riedel GF, Ferrier DP, Sanders JG (1991) Uptake of selenium by freshwater phytoplankton. Water Air Soil Pollut 57/58: $23-30$

Sanders JG, Riedel GF (1993) Trace element transformation during the development of an estuarine algal bloom. Estuar 16:521-532

Sanders RW, Gilmour CC (1994) Accumulation of selenium in a model freshwater microbial foodweb. Appl Environ Microbiol 60:2677-2683

Sandholm M, Oksanen HE, Pesonen L (1973) Uptake of selenium by aquatic organisms. Limnol Oceanogr 18:496-499

Strickland JDH, Parsons TR (1972) A practical handbook of seawater analysis, 2nd edn. Fisheries Research Board of Canada, Ottawa

Utermöhl H (1958) Zur Vervollkommnung der quantitativen Phytoplanktonmethodik. Mitt Int Ver Theor Angew Limnol 9:1-38

Vandermeulen J, Foda A (1988) Cycling of selenite and selenate in marine phytoplankton. Mar Biol 98:115-123

Watson SW, Novistsky TJ, Quinn HL, Valois FW (1977) Determination of bacterial number and biomass in the marine environment. Appl Environ Microbiol 33:940-946

Wehr JD, Brown L (1985) Selenium requirement of a bloomforming planktonic alga from softwater and acidified lakes. Can J Fish Aquat Sci 42:1783-1788

Wheeler AE, Zingaro RA, Irgolic K (1982) The effect of selenate, selenite and sulfate on six species of unicellular algae. J Exp Mar Biol Ecol 57:181-194

Wrench JJ (1978) Selenium metabolism in the marine phytoplankton Tetraselmis tetrathele and Dunaliella minuta. Mar Biol 49:231-236

Wrench JJ, Measures CT (1982) Temporal variations in dissolved selenium in a coastal ecosystem. Nature 299: $431-433$

Zhang GH, Hu M, Huang Y, Harrison PJ (1990) Selenium uptake and accumulation in marine phytoplankton and transfer of selenium to the clam Puditapes philippnarum. Mar Environ Res 30:179-190 